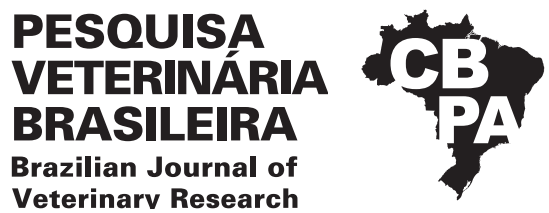

Pesq. Vet. Bras. 40(8):593-597, August 2020 DOI: $10.1590 / 1678-5150-P V B-6468$

Original Article Veterinarv Research

ISSN 0100-736X (Print)

ISSN 1678-5150 (Online)

\title{
Co-infection by Neopora caninum and bovine viral diarrhea virus in cattle from Rio Grande do Sul, Brazil, destined to exportation ${ }^{1}$
}

\author{
Marta E.M. Alves ${ }^{2}$, Fagner D’ambroso Fernandes ${ }^{2 *}$ (ID), Francielle L. Monteiro ${ }^{2}$, \\ Patricia Braunig ${ }^{2}$ (D), Juliana F. Cargnelutti², Eduardo F. Flores ${ }^{2}$ (D), \\ Rudi Weiblen ${ }^{2}$ and Fernanda S.F. Vogel ${ }^{2}$
}

\begin{abstract}
Alves M.E.M., Fernandes F.D., Monteiro F.L., Braunig P., Cargnelutti J.F., Flores E.F., Weiblen R. \& Vogel F.S.F. 2020. Co-infection by Neospora caninum and bovine viral diarrhea virus in cattle from Rio Grande do Sul, Brazil, destined to exportation. Pesquisa Veterinária Brasileira 40(8):593-597. Departamento de Medicina Veterinária Preventiva, Universidade Federal de Santa Maria, Avenida Roraima 1000, Santa Maria, RS 97105-900, Brazil. E-mail: fagnermedvet@gmail.com

Reproductive tests in cattle are of great economic importance, given the impact it can have on the production system and may be caused by agents. Neospora caninum and Bovine Viral Diarrhea virus (BVDV) are considered of great importance as reproductive and should be considered responsible for keeping animals persistently infected. The present study included 479 calf serum samples for export in the state of Rio Grande do Sul (RS). All samples were screened for BVDV by an ELISA antigen. BVDV antigen-positive ELISA samples were isolated from BVDV in cell culture. An indirect immunofluorescence (IFT) technique was used to detect anti- $N$. caninum antibodies. Of the 479 export-treated serum samples, 361 were positive for BVDV antigens by ELISA and/or viral isolation test (361/479-75.36\%), and 109 IFT-positive samples for N. caninum (109/479-22.75\%). Despite detection of antibodies anti-N. caninum did not differ statistically between naturally infected BVDV and non-BVDV infected animals suggesting that there is no interference of BVDV infection on infection or detection rate of animals with $N$. caninum, positive animals in viral isolation and high DO in BVDV-Ag ELISA. may present active disease and consequent immunosuppression, contributing to a potential reactivation of $N$. caninum.
\end{abstract}

INDEX TERMS: Coinfection, Neospora caninum, bovine viral diarrhea virus, cattle, Rio Grande do Sul, Brazil, exportation, BVDV.

RESUMO.- [Coinfecção por Neospora caninum e vírus da diarreia viral bovina em bovinos do Rio Grande do Sul, Brasil, destinados à exportação.] Testes reprodutivos em bovinos são de grande importância econômica, dado o impacto que podem ter no sistema de produção e podem ser causados por agentes. O Neospora caninum e o vírus da Diarreia Viral Bovina (BVDV) são considerados de grande importância como reprodutivos e devem ser considerados responsáveis por manter os animais persistentemente infectados. $\mathrm{O}$ presente estudo incluiu 479 amostras de soro de bezerro para exportação no estado do Rio Grande do Sul (RS). Todas as amostras foram rastreadas para BVDV por um antígeno

\footnotetext{
${ }^{1}$ Received on January 13, 2020.

Accepted for publication on June 5, 2020.

${ }^{2}$ Departamento de Medicina Veterinária Preventiva, Universidade Federal da Santa Maria (UFSM), Av. Roraima 1000, Camobi, Santa Maria, RS 97105900, Brazil. *Corresponding author: fagnermedvet@gmail.com
}

ELISA. As amostras de ELISA positivas para o antigénio BVDV foram isoladas a partir de BVDV em cultura de células. Uma técnica de imunofluorescência indireta (IFT) foi utilizada para detectar anticorpos anti- $N$ caninum. Das 479 amostras de soro tratadas para exportação, 361 foram positivas para antígenos de BVDV por ELISA e/ou teste de isolamento viral (361/479-75,36\%) e 109 amostras positivas para IFT para $N$. caninum (109/479-22,75\%). Apesar da detecção de anticorpos anti- $N$. caninum não diferiu estatisticamente entre animais infectados naturalmente BVDV e não BVDV sugerindo que não há interferência da infecção pelo BVDV na infecção ou taxa de detecção de animais com $N$. caninum, animais positivos em isolamento viral e alta DO em BVDV-Ag ELISA, pode apresentar doença ativa e consequente imunossupressão, contribuindo para uma potencial reativação de $N$. caninum.

TERMOS DE INDEXAÇÃO: Coinfecção, Neospora caninum, vírus da diarréia viral bovina, bovinos, Rio Grande do Sul, Brasil, exportação, BVDV. 


\section{INTRODUCTION}

Cattle reproductive diseases have great economic importance due to productive losses as return to estrus, abortion, long interval between births, birth of weak and unviable animals, birth reduction and increase in females discard rate (Dubey et al. 2007, Neta et al. 2010, Lanyon et al. 2014, Lilenbaum \& Martins 2014). Diverse etiological agents are related to bovine reproductive diseases and the most frequent are Neospora caninum (NC), Bovine Viral Diarrhea virus (BVDV), Leptospira spp., Bovine Herpesvirus type 1 (BoHV-1), Brucella spp., Campylobacter spp., Tritrichomonas spp., Chlamydia abortus, Coxiella burnetii (Kirkbride 1992, Morris et al. 2018, Olmo et al. 2018, Softic et al. 2018). Among these agents NC and BVDV have significant importance because they to promote reproductive losses and have the ability to establish persistent infections (Chernick et al. 2018).

Bovine pestivirus are worldwide important pathogens of cattle promoting reproductive, enteric, hemorrhagic and/or respiratory disorders (Dubovi 1994, Pellerin et al. 1994, Flores et al. 2000, Fulton et al. 2002). Three species of pestivirus are recognized affecting bovine: Bovine viral diarrhea virus types 1 (BVDV-1, or Pestivurus A), Bovine viral diarrhea virus types 2 (BVDV-2, or Pestivirus B) and HoBi-like (Pestivirus H). The maintenance of BVDV (and HoBi-like) in herds occurred mainly by persistent infected (PI) animals, that are BVDV immunotolerant. These animals are produced when seronegative cows are infected by BVDV at 40 to 120 days of pregnancy, and after birth, calves allow the virus replication in a variety of tissues and shed virus in secretions and excretions for their lifetime (McClurkin et al. 1984). Immunosuppression is a common consequence of BVDV infection in adult animals that facilitates secondary infections and disease severity (Brownlie 1990).

$\mathrm{NC}$ is a protozoan belonging to the phylum Apicomplexa and family Sarcocystidae (Dubey et al. 1999), it is widely distributed in the world and considered one of the main agent causing abortion in bovines (Dubey \& Schares 2011). The definitive hosts are domestic and wild canids (Gondim 2006) and $\mathrm{NC}$ is capable of infecting a wide range of intermediate hosts including bovine. In bovine, infection occurs via horizontal or vertical, and the vertical transmission is the most important in epidemiological aspect (Williams et al. 2009). Infection of pregnant cows promotes embryonic mortality, return to estrus, abortion, birth of weak animals, birth of animals with nervous signs and/or healthy but persistently infected animals (PI). PI calves are the main responsible for the maintenance of the agent in the herd and therefore they are extremely important in the epidemiology of the disease (Dubey et al. 2007). Besides that, transplacental infection by $N$. caninum may occur at any gestational stage and also may occur in subsequent pregnancies of persistently infected females due to the protozoa reactivation (Davison et al. 1999, Dubey et al. 2007).

BVDV frequently determine immunosuppression that contributes to subsequent infection by other agents or reactivation of latent agents and this viral infection also contributes to the severity of infection caused by other agents (Baker 1995). NC may be a secondary cause of abortion and also may potentialize abortion caused by other agents (Mineo et al. 2006, Asmare et al. 2012). BVDV and N. caninum co-infection is reported in other studies and suggested that should be related to higher rates of reproductive losses and consequently economic losses (Thurmond et al. 1997).

Thus, due the economic impact related to productive and reproductive losses caused by the infection with these two agents in herds, the present study aimed to determine the frequency of antibodies anti- $N$. caninum, BVDV antigen and the co-infection by $N$. caninum and BVDV in animals naturally infected destined to exportation.

\section{MATERIALS AND METHODS}

The current study included 479 sera samples of beef calves destined to exportation from Rio Grande do Sul state (RS). All samples were screened for BVDV by an antigen ELISA. Positive samples for BVDV antigen in ELISA were submitted to BVDV isolation in cell culture. Indirect immunofluorescence technique (IFT) was used for antibodies anti- $N$. caninum detection.

Samples. A total of 479 samples of beef sera were taken from calves destined for export was maintained under refrigeration $\left(4^{\circ} \mathrm{C}\right)$ until analyses.

Antigen ELISA. All 479 sera samples $(50 \mu \mathrm{l})$ were submitted to BVDV antigen ELISA (ELISA BVDV-Ag) using IDEXX BVDV Ag/ Serum Plus (code 9943830) and/or IDvet ID Screen BVDP80 Antigen Capture (code BVDAGP80-10P) kits. All procedures were performed according manufacture instructions. Samples were considered positive to BVDV antigen when corrected OD ration (OD sample - OD negative) was $>0.3$ and/or the $S / P$ ration was $\geq 0.2$, when IDEXX kit and IDVet kit were used, respectively.

Virus isolation. Virus isolation was performed into monolayers of MDBK cells by inoculating sera samples obtained from positive BVDV antigen ELISA ( $50 \mu \mathrm{l} /$ well of 24 -wells plate). Samples were submitted to 3 passages of 5 days each. The presence of viral antigens was assessed by submitting inoculated cells (at passage 3 ) to an indirect fluorescente antibody assay (IFA), using a pool of BVDV-specific monoclonal antibodies (MAbs) as primary antibodies (Corapi et al. 1990, Kreutz et al. 2000) and anti-mouse conjugated with fluorescein as secondary antibody. Samples were evaluated at 400x magnification under epifluorescence microscope (Carl Zeiss Germany, HBO 50/AC, Axiolab) using a 465-495nm excitation and 515-555nm emission filter.

Indirect immunofluorescence technique (IFT) for NC antibodies. The IFT was used to detect immunoglobulins-G against $\mathrm{NC}$ in the serum of animals. The IFT evaluation was performed using microscopy slides containing fixed tachyzoites of the NC-1 strain of NC. Sera samples were diluted 1:50 in PBS (pH 7.2) and incubated for $30 \mathrm{~min}$ at $37^{\circ} \mathrm{C}$ in a humid dark chamber. The secondary antibody used was bovine anti-IgG-fluorescein isothyocianate (FITC) conjugate for $30 \mathrm{~min}$ at $37^{\circ} \mathrm{C}$ in a humid dark chamber. Serum sample known as positive or negative was used as a control. Samples were evaluated at 400x magnification under epifluorescence microscope (Carl Zeiss - Germany, HBO 50/AC, Axiolab) using a $465495 \mathrm{~nm}$ excitation and $515-555 \mathrm{~nm}$ emission filter. We considered positive samples reactions that showed a peripheral or diffuse fluorescence in the tachyzoites surface, in contrast to apical or polar fluorescence that were considered negative samples (Paré et al. 1995).

Statistical analysis. Comparisons between the direct ELISA results for BVDV, BVDV isolation and the detection of anti-NC antibodies were analyzed using the Chi-square test. 


\section{RESULTS AND DISCUSSION}

From the 479 sera samples of calves destined to exportation, 361 were positive for BVDV antigens in ELISA and/or viral isolation test (361/479-75.36\%), and 109 positive samples in IFT for NC. (109/479-22.75\%). The detection of anti-Neospora caninum antibodies in animals naturally infected by BVDV was $23.27 \%(84 / 361)$ and $21.18 \%(25 / 118)$ in animals negative for BVDV antigen (Table 1).

The occurrence of anti-NC antibodies detected in the present study when the total serum samples were analyzed $(22.75 \%)$ is in accordance with serological studies realized in some Brazilian regions/states, as Goiás (27\%) (SANTIN et al., 2017) and Paraná (13.2\%) (Snak et al. 2018). There was not statistical difference in the frequency detection of antibody anti-NC in animals naturally infected with BVDV $(23.27 \%)$ and not infected $(21.18 \%)$, suggesting that in the bovines tested, the frequency of animals persistently infected with $N$. caninum should not be influenced by previously BVDV infection.

Studies conducted by He et al. (2004) in Australia and Lassen et al. (2012) in Estonia also did not found correlation between BVDV infection and Neospora spp. However, Chi Duong et al. (2008) found association between the presence of anti- $N$. caninum and anti-BVDV antibodies in cows from small farms in Vietnam and this association between the occurrence of Neospora spp. and BVDV antibodies was been previously described by Björkman et al. (1996) in Sweden. In Brazil, Melo et al. (2004) detected anti Neospora spp. and anti-BVDV antibodies in milk from cows, demonstrating co-existence between these two agents in the analyzed herd. Therefore, the levels of BVDV or NC infection and co-infection are associated with herd characteristic as size, beef or milk production system and sanitary conditions (Thurmond et al. 1997).

The presence of anti-Neospora spp. in animals that did not ingest colostrum and non-vaccinated indicates the occurrence of persistent infection (Dubey et al. 2007). Therefore, all animals that have antibodies to Neospora spp. diagnosed are persistently infected. The detection of BVDV virion or viral antigens indicates both acute infection (transiently infected animals - TI) or persistent infection (persistently infected animals - PI) (Bachofen et al. 2010). Therefore, serologically positive animals for Neospora spp. and positive for BVDV antigen in viral isolation or ELISA-Ag tests are considered to be co infected by these two agents. The viral and parasitological coexistence should be related to a series of epidemiological factors mainly the immunosuppression determined by BVDV (Melo et al. 2004).

Detection frequency of anti-NC. in positive- BVDV animals from viral isolation was $18.75 \%$, whereas positive - BVDV in ELISA-Ag and negative in viral isolation were $23.7 \%$ (Table 2). Concomitant infection by two agentes should be related to birth reduction rate, PI and TI animals usually suffer of immunosuppression caused by BVDV infection, which probably facilitate secondary infection by other agents, as $N$. caninum (Asmare et al., 2012). Pregnant cows co-infected with $N$. caninum and BVDV (female TI, female harboring PI calf, or female PI) would have higher rates of abortion and return to estrus than monoinfected cows and this occurs because co-infections potentialize the negative reproductive effects in cattle caused by both agents (Bjorkman et al. 2000, Wouda et al. 1998, Quinn et al. 2004).

Analyzing OD results obtained in ELISA, the detection frequency of anti-Neospora spp. antibodies is higher when OD is above 1.01 (Table 3). Higher OD in direct anti-BVDV ELISA is related to higher antigen detection and consequently higher probability of BVDV PI animals (Cornish et al. 2005). When BVDV isolation in cell culture was possible, it was observed that from the six positive animals for both agents BVDV and N. caninum, five had high OD in ELISA (Table 3). Analyzing the negative samples, a similar tendency is observed.

Monoinfection or co-infection with N. caninum and BVDV is associated with reproductive losses at any stage of gestation (Wouda et al. 1998) and despite of the detection of antibodies anti-N.caninum did not differ statistically between animals naturally infected by BVDV and not BVDV infected suggesting that there is not interference of BVDV infection in the infection or detection rate of animals with $N$. caninum, animals positive in viral isolation and with high OD in BVDV-Ag ELISA may

Table 1. Detection of anti-Neospora caninum in animals naturally infected by BVDV

\begin{tabular}{|c|c|c|c|c|c|c|c|c|c|}
\hline \multirow{3}{*}{$\begin{array}{c}\text { ELISA } \\
\text { BVDV-Ag }\end{array}$} & \multicolumn{4}{|c|}{ Anti-Neospora caninum IgG } & \multirow{3}{*}{$\begin{array}{l}\text { BVDV viral } \\
\text { isolation }\end{array}$} & \multicolumn{4}{|c|}{ Anti-Neospora caninum IgG } \\
\hline & \multicolumn{2}{|r|}{ Positive } & \multicolumn{2}{|c|}{ Negative } & & \multicolumn{2}{|c|}{ Positive } & \multicolumn{2}{|c|}{ Negative } \\
\hline & Number & Percentual (\%) & Number & Percentual (\%) & & Number & Percentual (\%) & Number & Percentual (\%) \\
\hline Positive (361) & 84 & 23.27 & 277 & 76.73 & Positive & $6^{*}$ & 18,75 & 26 & 81,25 \\
\hline Negative (118) & 25 & 21.18 & 93 & 78.82 & Negative & 78 & 23,70 & 251 & 76,3 \\
\hline Total (479) & 109 & 22.75 & 370 & 77.25 & Total & 84 & 100 & 277 & 100 \\
\hline
\end{tabular}

Table 3. Results obtained in ELISA

\begin{tabular}{|c|c|c|c|c|c|c|c|}
\hline \multirow{3}{*}{$\begin{array}{c}\text { ELISA BVDV-Ag } \\
\text { OD }\end{array}$} & \multirow{2}{*}{\multicolumn{2}{|c|}{$\begin{array}{c}\text { Positive BVDV isolation } \\
\text { anti-Neospora caninum IgG }\end{array}$}} & \multirow{2}{*}{\multicolumn{2}{|c|}{$\begin{array}{c}\text { Negative BVDV isolation } \\
\text { anti-Neospora caninum IgG }\end{array}$}} & \multirow{3}{*}{ TOTAL } & \multirow{2}{*}{\multicolumn{2}{|c|}{ anti-Neospora caninum IgC }} \\
\hline & & & & & & & \\
\hline & + & - & + & - & & + & - \\
\hline Lower $0.3^{*}$ & - & - & 25 & 93 & 118 & 25 & 93 \\
\hline 0.3-1.0 & 1 & 8 & 57 & 194 & 260 & 58 & 202 \\
\hline $1.01-2.0$ & 0 & 4 & 14 & 36 & 54 & 14 & 40 \\
\hline Above 2,01 & 5 & 14 & 7 & 21 & 47 & 12 & 35 \\
\hline TOTAL & 6 & 26 & 78 & 251 & 361 & 109 & 370 \\
\hline
\end{tabular}


present active disease and consequently imunnosupression as disease consequence contributing to a potential $N$. caninum reactivation. Although the samples in this study were obtained from animals destined to exportation, and the reproductive history of the original properties is unknown, the results suggested the occurrence of infection with $N$. caninum and/ or BVDV and that should be related to reproductive problems and consequently economic losses.

\section{CONCLUSIONS}

The present study reinforces the importance and occurrence of Neospora caninum and BVDV as pathogens infecting bovines and although the demonstrated low occurrence of co-infection, these agents are circulating in bovine herds and consequently causing damage to health, reproduction and animal production.

Further research should be conducted in animals infected by the two agents to more clearly determine the importance of $\mathrm{BVDV}$ and $\mathrm{NC}$ co-infection in the reproductive rates of cattle.

Conflict of interest statement.- There are no conflicts of interest.

\section{REFERENCES}

Asmare K., Regassa F., Robertson L.J., Martin A.D. \& Skjerve E. 2012. Reproductive disorders in relation to Neospora caninum, Brucella spp. and bovine viral diarrhoea virus serostatus in breeding and dairy farms of central and southern Ethiopia. Epidemiol. Infect. 141(8):1-9. <https://dx.doi.org/10.1017/S0950268812002191><PMid:23034138>

Bachofen C., Braun U., Hilbe M., Ehrensperger F., Stalder H.P. \& Peterhans E. 2010. Clinical appearance and pathology of cattle persistently infected with bovine viral diarrhoea virus of different genetic subgroups, Vet. Microbiol. 141(3/4):258-267. <https://dx.doi.org/10.1016/j.vetmic.2009.09.022> $<$ PMid:19819088>

Baker J.C. 1995. The clinical manifestations of bovine viral diarrhoea infection. Vet. Clin. N. Am., Food Anim. Pract. 11(3):425-445. <https://dx.doi.org/10.1016/S0749-0720(15)30460-6><PMid:8581856>

Bjorkman C., Alenius S., Manuelsson L. \& Uggla A. 2000. Neospora caninum and bovine virus diarrhoea virus infections in Swedish dairy cows in relation to abortion. Vet. J. 159(2):201-206. <https://dx.doi.org/10.1053/ tvjl.1999.0446><PMid:10712809>

Björkman C., Johansson O., Stenlund S., Holmdahl J.O. \& Uggla A. 1996. Neospora species infection in a herd of dairy cattle. J. Am. Vet. Med. Assoc. 208(9):1441-1444.<PMid:8635995>

Brownlie J. 1990. Pathogenesis of mucosal disease and molecular aspects of bovine virus diarrhea virus. Vet. Microbiol. 23(1/4):371-382. <https://dx.doi.org/10.1016/0378-1135(90)90169-V>

Chernick A., Ambagala A., Orsel K., Wasmuth J.D., Marle G. van. \& Meer F. van. 2018. Bovine viral diarrhea virus genomic variation within persistently infected cattle. Infect. Genet. Evol. 58:218-223. <https://dx.doi.org/10.1016/j. meegid.2018.01.002 > <PMid:29306002>

Chi Duong M., Alenius S., Huong L.T. T. \& Björkman C. 2008. Prevalence of Neospora caninum and bovine viral diarrhoea virus in dairy cows ins Southern Vietnam. Vet. J. 175(3):390-394. <https://dx.doi.org/10.1016/j. tvjl.2006.01.016> <PMid:17349807>

Corapi W.V., Donis R.O. \& Dubovi E.J. 1990. Characterization of a panel of monoclonal antibodies and their use in the study of the antigenic diversity of bovine viral diarrhea virus. Am. J. Vet. Res. 51(9):1388-1394. $<$ PMid:2168687>

Cornish T.E., van Olphen A.L., Cavender J.L., Edwards J.M., Jaeger P.T., Vieyra L.L., Woodard L.F., Miller D.R. \& O'Tolle D. 2005. Comparison of ear notch immunohistochemistry, ear notch antigen-capture ELISA, and buffy coat vírus isolation for detection of calves persistently infected with bovine viral diarrhea virus. J. Vet. Diagn. Invest. 17(2):110-117. <https://dx.doi.org/10.1177/104063870501700203><PMid:15825490>

Davison H.C., Guy F., Trees A.J., Ryce C., Ellis J.T., Otter A., Jeffrey M., Simpson V.R. \& Holt J.J. 1999. In vitro isolation of Neospora caninum from a stillborn calf in the UK. Res. Vet. Sci. 67(1):103-105.<https://dx.doi.org/10.1053/ rvsc.1998.0272><PMid:10425249>

Dubey J.P. \& Schares G. 2011. Neosporosis in animals - the last five years. Vet. Parasitol. 180(1/2):90-108. <http://dx.doi.org/10.1016/j.vetpar.2011.05.031> <PMid:21704458>

Dubey J.P., Schares G. \& Ortega-Mora L.M. 2007. Epidemiology and control of Neosporosis and Neospora caninum. Clin. Microbiol. Rev. 20(2):323367. <https://dx.doi.org/10.1128/CMR.00031-06><PMid:17428888>

Dubey J.P., Venturini M.C., Venturini L., McKinney J. \& Pecoraro M. 1999. Serologic prevalence of Sarcocystis neurona, Toxoplasma gondii and Neospora caninum in horses in Argentina. Vet. Parasitol. 86(1):59-62. <http://dx.doi.org/10.1016/S0304-4017(99)00127-2><PMid:10489203>

Dubovi E.J. 1994. Impact of bovine diarrhea virus on reproductive performance in cattle. Vet. Clin. N. Am., Food Anim. Pract. 10(3):503-514. <https://dx.doi. org/10.1016/S0749-0720(15)30535-1><PMid:7728633>

Flores E.F., Gil L.H., Botton S.A., Weiblen R., Ridpath J.F., Kreutz L.C., Pilati C., Driemeyer D., Moojen V. \& Wendelstein A.C. 2000. Clinical, pathological and antigenic aspects of bovine viral diarrhea virus (BVDV) type2 isolates identified in Brazil. Vet. Microbiol. 77(1/2):175-183. <https://dx.doi.org/10.1016/S0378-1135(00)00274-1><PMid:11042411>

Fulton R.W., Cook B.J., Step D.L., Confer A.W., Saliki J.T., Payton M.E., Burge L.J., Welsh R.D. \& Blood K.S. 2002. Evaluation of health status of calves and the impact on feedlot performance: assessment of a retained ownershipprogram for postweaning calves. Can. J. Vet. Res. 66(33):173-180.<PMid:12146889>

Gondim L.F.P. 2006. Neospora caninum in wildlife. Trends Parasitol. 22(6):247252. <https://dx.doi.org/10.1016/j.pt.2006.03.008> <PMid:16616642>

He Q., Windsor P.A. \& Kirkland P.D. 2004. An outbreak of abortion in a dairy herd associated with Neospora caninum and bovine pestivirus infection. Austr.Vet.J. 82(1/2):99-101.<http://dx.doi.org/10.1111/j.1751-0813.2004. tb14656.x><PMid:15088970>

Kirkbride C.A. 1992. Etiologic agents detected in a 10-year study of bovine abortions and stillbirths. J. Vet. Diagn. Invest. 4(2):175-180. <http://dx.doi.org/10.1177/104063879200400210><PMid:1616982>

Kreutz L.C., Donis R.O., Gil L.H.V.G., Hoffman A.N., Garcez D.C., Flores E.F. \& Weiblen R. 2000. Production and characterization of monoclonal antibodies to Brazilian isolates of bovine viral diarrhea virus. Braz. J. Med. Biol. Res. 33(12):1459-1466. <http://dx.doi.org/10.1590/S0100879X2000001200010>

Lanyon S.R., Colina F.I., Reichel M.P. \& Brownlie J. 2014. Bovine viral diarrhoea: pathogenesis and diagnosis. Vet. J. 199(2):201-209. <https://dx.doi. org/10.1016/j.tvjl.2013.07.024> <PMid:24053990>

Lassen B., Orro T., Aleksejev A., Raaperi K., Javis T. \& Viltrop A. 2012. Neospora caninum in Estonian dairy herds in relation to herd size, reproduction parameters, bovine virus diarrhoea virus, and bovine herpes virus 1. Vet. Parasitol. 190(2012):43-50. <https://dx.doi.org/10.1016/j. vetpar.2012.05.021><PMid:22721941>

Lilenbaum W. \& Martins G. 2014. Leptospirosis in cattle: a challenging scenario for the understanding of the epidemiology. transboundary and emerging diseases. 61(Suppl.1):63-68. <http://dx.doi.org/10.1111/tbed.12233> <PMid:25135465>

McClurkin A.W., Littledike E.T., Cutlip R.C., Frank G.H., Coria M.F. \& Bolin S.R. 1984. Production of cattle immunotolerant to bovine viral diarrhea virus. Can. J. Comp. Med. 48(2):156-161. <PMid:6326980>

Melo C.B., Leite R.C. \& Lobato Z.I.P. 2004. Infection by Neospora caninum associated with bovine herpesvirus 1 and bovine viral diarrhea virus in 
cattle from Minas Gerais state, Brazil. Vet. Parasitol. 119(2/3):97-105. <http://dx.doi.org/10.1016/j.vetpar.2003.12.002><PMid:14746970>

Mineo T.W.P, Alenius S., Näslund K., Montassier H.J. \& Björkman C. 2006. Distribution of antibodies against Neospora caninum, BVDV and BHV-1 among cows in Brazilian dairy herds with reproductive disorders. Rev. Bras. Parasitol. Vet. 15(4):188-192. <PMid:17196123>

Morris J.M., Sookhoo J., Blake L., Jordan A.B., John J., Ali S., Sarjusingh G., Aime J.S., Amoroso E.H. \& Oura C.A.L. 2018. Serosurvey for infectious agents associated with subfertility and abortion in dairy cattle in Trinidad and Tobago, West Indies. Vet. Sci. 5(2):51. <https://dx.doi.org/10.3390/ vetsci5020051><PMid:29751649>

Neta A.V.C., Mol J.P.S., Xavier M.N., Paixão T.A., Lage A.P. \& Santos R.L. 2010. Pathogenesis of bovine brucellosis. Vet. J. 184(2):146-155. <https://dx.doi. org/10.1016/j.tvjl.2009.04.010> <PMid:19733101>

Olmo L., Dye M.T., Reichel M.P., Young J.R., Nampanya S., Khounsy S., Thomson P.C., Windsor P.A. \& Bush R.D. 2018. Investigation of infectious reproductive pathogens of large ruminants: are neosporosis, brucellosis, leptospirosis and BVDV of relevance in Lao PDR? Acta Tropica 177:118-126. <https://dx.doi.org/10.1016/j.actatropica.2017.10.007>

Paré J., Hietala S.K. \& Thurmond M.C. 1995. Interpretation of an indirect fluorescent antibody test for diagnosis of Neospora sp. infection in cattle. J. Vet. Diagn. Invest. 7(2):273-275.<http://dx.doi.org/10.1177/104063879500700222> <PMid:7619917>

Pellerin C., Hurk J.V.D., Lecomte J. \& Tijssen P. 1994. Identification of a new group of bovine viral diarrhea virus strains associated with severe outbreaks and high mortalities. Virology 203(2):260-268. <http://dx.doi. org/10.1006/viro.1994.1483><PMid:8053150>
Quinn H., Windsor P.A., Kirkland P.D. \& Ellis J.T. 2004. An outbreak of abortion in a dairy herd associated with Neospora caninum and bovine pestivirus infection. Austr. Vet. J. 82(1/2):99-101.<http://dx.doi.org/10.1111/j.1751-0813.2004. tb14656.x><PMid:15088970>

Santin A.P., Juliano R.S., Silva A.C., Oliveira V.S.F., Kipnis-Junqueira A.P., Brito W.M.E.D. \& Fioranti M.C.S. 2017. Curraleiro cattle breed health status for neosporosis and toxoplasmosis. Ciênc. Anim. Bras. 18:1-8. <http://dx.doi. org/10.1590/1089-6891v18e-44649>

Snak A., Garcia F.G., Lara A.A., Pena H.F.J. \& Osaki S.C. 2018. Neospora caninum in properties in the west region of Paraná, Brazil: prevalence and risk factors. Revta Bras. Parasitol. Vet. 27(1):51-59. <http://dx.doi. org/10.1590/s1984-29612018001>

Softic A., Asmare K., Granquist E.G., Godfroid J., Fejzic N. \& Skjerve E. 2018 The serostatus of Brucella spp., Chlamydia abortus, Coxiella burnetii and Neospora caninum in cattle in three cantons in Bosnia and Herzegovina. BMC Vet. Res. 14(1):40.<http://dx.doi.org/10.1186/s12917-018-1361-z>

Thurmond M.C., Hietala S.K. \& Blanchard C.P. 1997. Herd-based diagnosis of $N$. caninum-induced endemic and epidemic abortion in cows and evidence for congenital and postnatal transmission. J. Vet. Diagn. Invest. 9(1):44-49. <https://dx.doi.org/10.1177/104063879700900108><PMid:9087924>

Williams D.J., Hartley C.S., Björkman C. \& Trees A.J. 2009. Endogenous and exogenous transplacental transmission of Neospora caninum- how the route of transmission impacts on epidemiology and control of disease. Parasitology 136(14):1895-1900. <https://dx.doi.org/10.1017/S0031182009990588> $<$ PMid:19691862>

Wouda W., Moen A.R. \& Schukken Y.H. 1998. Abortion risk in progeny of cows after a Neospora caninum epidemic. Theriogenology 49(7):1311-1316. <https://dx.doi.org/10.1016/S0093-691X(98)00078-8> 